\title{
TEMU KEMBALI CITRA TENUN NUSA TENGGARA TIMUR MENGGUNAKAN EKSTRAKSI FITUR YANG ROBUST TERHADAP PERUBAHAN SKALA, ROTASI DAN PENCAHAYAAN
}

\author{
Budiman Baso $^{* 1}$, Nanik Suciati ${ }^{2}$ \\ ${ }^{1,2}$ Fakultas Teknologi Informasi dan Komunikasi, Institut Teknologi Sepuluh Nopember Surabaya \\ Email: ${ }^{1}$ budimanbaso@gmail.com, ${ }^{2}$ nanik@if.its.ac.id \\ *Penulis Korespondensi
}

(Naskah masuk: 14 Mei 2019, diterima untuk diterbitkan: 10 Februari 2020)

\begin{abstract}
Abstrak
Ragam motif pada tenun Nusa Tenggara Timur (NTT) seperti flora, fauna dan geometris menjadi suatu keunikan yang dapat membedakan daerah asal dan jenis dari tenun tersebut. Pada penelitian ini, sistem temu kembali citra berbasis isi atau Content-Based Image Retrieval (CBIR) diimplementasikan pada citra tenun NTT sehingga user dapat mencari citra tenun pada database menggunakan citra query berdasarkan fitur visual yang terkandung dalam citra. Seringkali citra query yang diinputkan user memiliki skala, rotasi dan pencahayaan yang bervariasi, sehingga diperlukan suatu metode ektraksi fitur yang dapat mengakomodasi variasi tersebut. Sistem temu kembali citra tenun pada penelitian ini menggunakan model Bag of Visual Words (BoVW) dari keypoints pada citra yang diekstrak dengan metode Speeded Up Robust Feature (SURF). BoVW dibangun menggunakan KMeans untuk menghasilkan visual vocabulary dari keypoints pada seluruh citra training. Representasi BoVW diharapkan dapat menangani variasi skala dan rotasi pada citra. Sedangkan untuk mengatasi variasi pencahayaan pada citra, dilakukan perbaikan kualitas citra dengan menggunakan Contrast Limited Adaptive Histogram Equalization (CLAHE). Percobaan dilakukan dengan membandingkan kinerja dari representasi BoVW yang dibangun menggunakan fitur SURF dengan Maximally Stable Extremal Regions (MSER) pada temu kembali citra tenun. Hasil uji coba menunjukkan bahwa metode SURF menghasilkan rata-rata akurasi 89,86\% dan waktu komputasi 9,94 detik, sedangkan MSER menghasilkan rata-rata akurasi 84,04\% dan waktu komputasi 1,95 detik.
\end{abstract}

Kata kunci: Content-Based Image Retrieval, Tenun Nusa Tenggara Timur, CLAHE, Bag of Visual Words, Speeded Up Robust Feature, Maximally Stable Extremal Regions.

\section{CONTENT-BASED IMAGE RETRIEVAL OF EAST NUSA TENGGARA TENUN USING ROBUST EXTRACTION FEATURES AGAINST SCALE, ROTATION AND LIGHTING CHANGES}

\begin{abstract}
The variety of motifs in East Nusa Tenggara tenun such as flora, fauna and geometric is an unique thing that can distinguish the region of origin and type of the tenun. In this study, the Content-Based Image Retrieval (CBIR) system is implemented in the tenun image. With Content-based techniques Users can search tenun images on the image database by using query images based on visual features contained in the image. Often the query image that the user enters has a different scale, rotation and lighting, so a feature extraction method is needed that can accommodate these differences. The tenun image retrieval system in this study used the Bag of Visual Words $(B o V W)$ model of the keypoints in the extracted image using the Speeded Up Robust Feature (SURF) method. BoVW was built using K-Means to produce visual vocabulary from keypoints on all training images. The representation of $\mathrm{BoVW}$ is expected to be able to handle scale variations and rotations in images. Whereas to overcome the lighting variations in the image, image quality improvement is done by using Contrast Limited Adaptive Histogram Equalization (CLAHE). The experiment was conducted by comparing the performance of the BoVW representation which was built using the SURF feature with Maximally Stable Extremal Regions (MSER) at the tenun image retrieval. The results of the trial showed that SURF obtained higher accuracy in all conditions of tenun image data with an average value of $89.86 \%$ whereas MSER obtained an average accuracy value of $84.04 \%$. But MSER's computation time is 1.95 seconds faster than SURF which is 9.94 seconds.
\end{abstract}

Keywords: Content-Based Image Retrieval, Tenun of Nusa Tenggara Timur, CLAHE, Bag of Visual Words, Speeded Up Robust Feature, Maximally Stable Extremal Regions. 


\section{PENDAHULUAN}

Tenun merupakan salah satu warisan budaya Indonesia dalam bentuk kain tradisional yang memiliki ragam motif. Salah satu provinsi di Indonesia yang dikenal memiliki motif tenun yang beragam adalah Nusa Tenggara Timur (NTT) atau dikenal dengan FLOBAMORA (Tallo, 2003). Motif yang terdapat pada tenun merupakan pola bentuk atau corak yang muncul secara berulang-ulang. Setiap daerah di NTT memiliki ciri khas motif masing-masing yang merupakan bentuk kebudayaan dan kepercayaan masyarakat setempat. Ragam hias yang terdapat dalam motif tenun NTT seperti flora, fauna dan geometris menjadi suatu keunikan yang membedakan setiap daerah asal dan filosofi suatu motif. Motif yang beragam pada kain tenun dapat berfungsi sebagai fitur atau karakteristik dalam mengidentifikasi asal usul dan jenis dari kain tenun tersebut (Tallo, 2003).

Pelestarian tenun Nusa Tenggara Timur (NTT) perlu diperhatikan karena baru sebagian dari jenis tenun NTT yang telah diusulkan pemerintah melalui Kementerian Pendidikan dan Kebudayaan sebagai warisan budaya tak benda ke UNESCO untuk kategori Need of Urgent Safeguarding of Intangible Cultural Heritage (Warisan Budaya Tak benda yang Membutuhkan Perlindungan Mendesak). Dalam hal ini tenun ikat Sumba yang merupakan salah satu jenis tenun di NTT yang dianggap dapat mewakili tradisi pertenunan di Indonesia (Setiawan, 2014).

Posisi Nusa Tenggara Timur (NTT) yang berbatasan langsung dengan negara Timor Leste yang memiliki budaya yang erat dengan NTT salah satunya adalah budaya tenunnya. Oleh karena itu proses pendataan tenun NTT perlu dilakukan secara komputerisasi sehingga dapat memberi kemudahan dalam mengakses dan mengolah data motif tenun tersebut, disamping itu juga sebagai bentuk pelestarian budaya tenun dengan melakukan digitasi kain tradisional Nusa Tenggara Timur (NTT). Apabila seluruh data tentang tenun hanya tersimpan secara konvensional, maka penyimpanan data yang berupa citra tenun tersebut menjadi terbatas dan tidak permanen. Selain itu, proses untuk melakukan pencarian kembali suatu citra akan rumit sehingga mengakibatkan proses pencarian citra tenun menjadi tidak efisien dan tidak efektif. Permasalahan tentang cara menyimpan data citra tenun secara konvensional dalam jumlah besar telah memiliki solusi, salah satunya adalah penggunaan database. Namun, karena jumlah data bertambah, saat ini permasalahan berkembang ke arah cara pencarian citra tenun di dalam suatu kumpulan data citra yang besar tersebut.

Penelitian yang mengangkat tenun sebagai objek penelitian dilakukan Setiohardjo and Harjoko, 2014 dengan melakukan analisis tekstur untuk klasifikasi motif kain tenun. Penelitian tersebut bertujuan untuk mengetahui diantara pendekatan analisis tekstur menggunakan metode Gray Level
Co-occurrence Matrix (GLCM) dikombinasikan dengan momen warna dan pendekatan analisis tekstur menggunakan Color Co-occurrence Matrix (CCM) untuk menganalisis tekstur tenun, metode manakah yang memberikan hasil lebih baik untuk klasifikasi motif kain tenun. Hasil penelitian menunjukkan bahwa untuk klasifikasi motif kain tenun, pendekatan analisis tekstur menggunakan metode CCM dengan metode klasifikasi KNN memberikan hasil lebih baik dengan tingkat akurasi tertinggi yaitu sebesar $80 \%$. Adapun penelitian yang dilakukan oleh Amalia, Indrawati and Yusnimar M. Amin, 2018 menggunakan metode ekstraksi fitur tekstur Gray Level Co-occurrence Matrix (GLCM) untuk citra songket. Hasil ekstraksi fitur digunakan untuk pendataan citra songket Aceh. Namun dari penelitian yang telah dilakukan belum dapat menjelaskan apakah metode ekstraksi fitur yang digunakan robust terhadapat variasi skala dan rotasi pada data citra kain tradisional yang digunakan.

Berikutnya penelitian oleh Nasir, Suciati and Wijaya, 2017 melakukan temu kembali citra kain tradisional dengan kombinasi fitur tekstur Local Binary Pattern (LBP) yang invariant terhadap rotasi dengan fitur warna berbasis ruang warna HSV pada batik dan songket. Hasil kombinasi fitur tekstur LBP yang invariant terhadap rotasi dengan fitur warna dari ruang warna HSV menghasilkan recall terbaik $100 \%$ pada dataset Batik dan $100 \%$ pada dataset Songket. Adapun penelitian Oksaputri, Ernawati and Desi Andreswari, 2018 menggunakan metode ekstraksi keypoint pada citra yang invarian terhadap skala dan rotasi yaitu Speeded Up Robust Features (SURF) untuk temu kembali citra batik besurek yang tidak utuh, untuk proses matching digunakan Library Approximated Nearest Neighbor (FLANN). Data yang digunakan yaitu 67 citra batik besurek dengan motif rembulan, burung kuau, burung kuau dan raflesia, kaligrafi, raflesia dan kaligrafi, dan raflesia. Hasil akurasi tertinggi adalah $86,1 \%$ pada motif rembulan, precision tertinggi pada motif kaligrafi dan raflesia yaitu $78,82 \%$, dan recall tertinggi pada motif rembulan yaitu $100 \%$.

Penelitian Alkhawlani, Elmogy and Elbakry, 2015 membandingkan dua teknik deskriptor fitur lokal yang invarian terhadap skala \& rotasi yaitu Scale-Invariant Feature Transform (SIFT) dan Speeded Up Robust Feature (SURF) dengan model Bag of Visual Words (BoVW) dan menggunakan Kmeans clustering untuk membangun visual vocabulary. Hasil dari eksperiment menunjukkan bahwa SURF memiliki komputasi yang cepat dan tahan terhadap pencahayaan dibandingkan SIFT pada Dataset Logo Flickr.

Dalam mendapatkan fitur berupa keypoint dari deskriptor fitur lokal Scale-Invariant Feature Transform (SIFT) dan Speeded Up Robust Feature (SURF) yang tahan terhadap variasi skala \& rotasi, terkadang pada citra yang dihasilkan memiliki 
pencahayaan kurang baik sehinggah menyebabkan hidden fiture atau sebagian fitur tidak dapat di deteksi, oleh karena itu Joo and Jeon, 2017 menggunakan Contrast Limited Adaptive Histogram Equalization (CLAHE) sebagai preprocessing untuk SIFT dalam mengekstrak keypoint pada citra panorama alam yang memiliki kecerahan yang tidak merata. Adapun Ismail, Ali and Farag, 2015 menggunakan perbaikan citra CLAHE dengan ekstraksi fitur SURF untuk proses pengenalan citra iris mata.

Pencarian citra dengan teknik Content-based dilakukan berdasarkan fitur yang terkandung dalam citra itu sendiri. Dengan menggunakan citra query, user dapat mencari citra tenun berdasarkan kesamaan motif pada kumpulan citra tenun yang terdapat dalam database. Namun pada kenyataannya dalam menghasilkan citra tenun yang akan diproses, pada saat pengambilan citra terkadang user kurang mempertimbangkan skala, rotasi, dan pencahayaan sehingga diperlukan suatu metode ektraksi fitur yang invariant terhadap skala dan rotasi yaitu Speeded Up Robust Feature (SURF) (Adikara, 2018). Untuk mengatasi distribusi kecerahan pada citra yang terkonsentrasi dalam rentang tertentu dilakukan perbaikan kualitas citra menggunakan Contrast Limited Adaptive Histogram Equalization (CLAHE).

Teknik yang dilakukan pada sistem temu kembali citra tenun Nusa Tenggara Timur pada penelitian ini yaitu melakukan preprocessing dengan mentransformasi citra RGB tenun menjadi citra grayscale lalu melakukan perbaikan pada citra tenun dengan menggunakan Contrast Limited Adaptive Histogram Equalization. Setelah mendapatkan citra tenun hasil preprocessing selanjutnya dengan menggunakan model Bag of Visual Words (BoVW) dari keypoints pada citra tenun yang diekstrak dengan metode Speeded Up Robust Feature (SURF). Model BoVW dibangun menggunakan K-Means sebagai algoritma pengelompokan untuk menghasilkan visual vocabulary dari keypoints pada seluruh citra training pada database. Dan selanjutnya menghitung jarak kedekatan antara citra query terhadap citra database untuk temu kembali citra tenun menggunakan jarak Euclidean distance.

\section{METODE PENELITIAN}

Pada Penelitian ini terdiri dari 4 tahapan. Proses diawali dengan preprocessing dimana pada citra database dan citra query yang semula adalah citra RGB di konversi menjadi citra grayscale lalu melakukan perbaikan kontras citra tenun dengan menggunakan Contrast Limited Adaptive Histogram Equalization (CLAHE). Setelah itu dengan menggunakan kombinasi Bag of Visual Words (BoVW) yang diekstraksi dengan menggunakan Speeded Up Robust Feature (SURF) sehingga menghasilkan vektor fitur (feature vector). Selanjutnya menghitung kesamaan fitur antara citra query dengan citra yang ada pada database. Hasil yang didapatkan adalah citra temu kembali berupa citra tenun Nusa Tenggara Timur berdasarkan kesamaan motif. Desain sistem ditunjukkan pada Gambar 1.

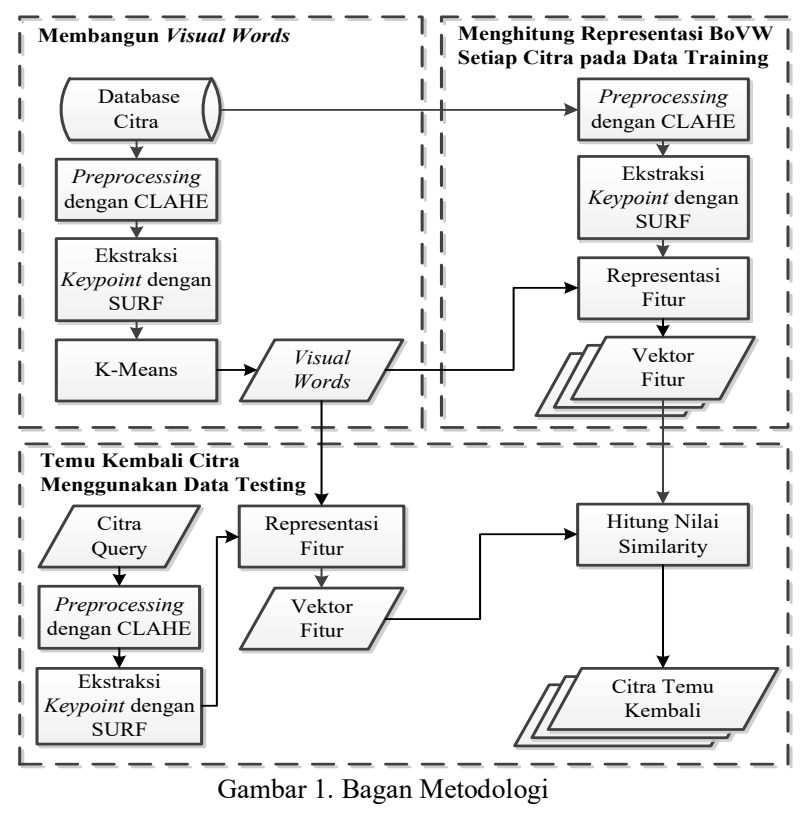

\subsection{Preprocessing}

Pada tahapan ini akan dilakukan analisis terhadap data yang telah dikumpulkan yang merupakan data masukan. Data masukan ini terdiri dari citra database maupun citra query. Tahapan yang dianalisis pada tahap ini adalah konversi citra input yang semula adalah citra RGB menjadi citra grayscale terlebih dahulu. Selanjutnya melakukan perbaikan kontras pada citra tenun dengan menggunakan Contrast Limited Adaptive Histogram Equalization (CLAHE). Dengan menggunakan CLAHE dapat mengatasi peningkatan kontras yang terlalu over pada AHE, karena kontras yang terlalu over dapat menyebabkan fitur yang terdapat pada motif tenun tidak dapat terbaca secara keseluruhan oleh SURF. Tahapan alur preprocessing dapat dilihat dalam Gambar 2. Adapun contoh hasil Preprocessing citra tenun setelah dilakukan perbaikan citra dengan CLAHE dapat dilihat pada Gambar 3(c).

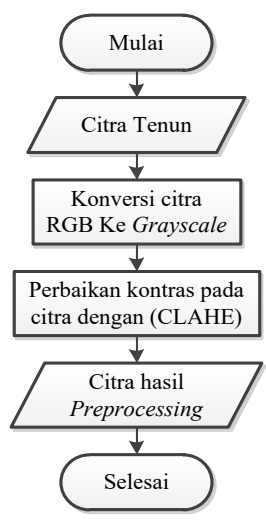

Gambar 2. Alur tahap Preprocessing 


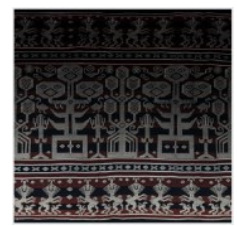

(a)

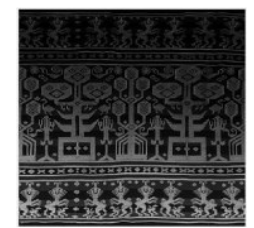

(b)

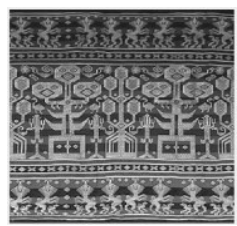

(c)
Gambar 3. Prepocessing Citra (a) Citra RGB (b) Citra grayscale (c) Citra setelah CLAHE

Contrast Limited Adaptive Histogram Equalization (CLAHE) merupakan teknik perbaikan kekontrasan pada citra dengan meningkatkan kontras lokal citra. Agar peningkatan kontras tidak terlalu over maka pada CLAHE diberikan nilai batas pada histogram. Nilai batas ini disebut dengan clip limit dimana menyatakan batas maksimum tinggi suatu histogram. Histogram diatas nilai clip limit dianggap kelebihan (excess) piksel yang akan didistribusikan kepada area sekitar dibawah clip limit sehingga histogram merata (Pizer et al., 2007). Untuk menghitung clip limit suatu histogram didefinisikan pada persamaan (1). Sedangkan contoh hasil histogram perbaikan citra tenun dengan CLAHE dapat dilihat pada Gambar 4(b).

$\beta=\frac{M}{\mathrm{~N}}\left(1+\frac{\alpha}{100}\left(S_{\max }-1\right)\right)$

Variabel $M$ menyatakan luas region size, $\mathrm{N}$ merupakan nilai grayscale dan $\alpha$ merupakan clip factor yang menyatakan penambahan batas limit suatu histogram bernilai 0 sampai 100 .
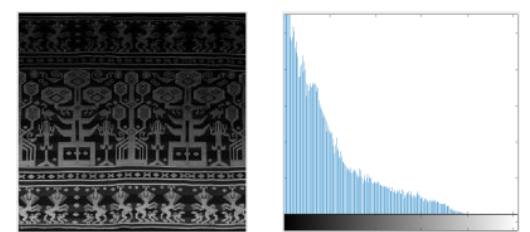

(a)
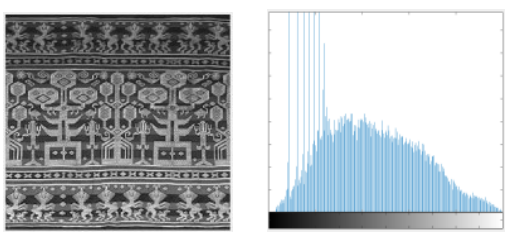

(b)

Gambar 4. Perbaikan Citra (a) Histogram Citra Sebelum CLAHE (b) Histogram Citra Setelah CLAHE dengan nilai clip limit 0.02

\subsection{Ekstraksi Fitur}

Pada tahapan ini akan dilakukan ekstraksi fitur pada citra tenun yang sebelumnya telah melewati tahapan preprocessing, ekstraksi fitur menggunakan metode Speeded Up Robust Feature (SURF). Pada proses awal ekstraksi fitur, citra tenun hasil preprocessing dilakukan proses deteksi keypoints. Setelah mendapatkan keypoints dilakukan proses ekstraksi fitur pada setiap point tersebut. Kemudian hasil fitur tersebut disimpan dalam fitur vektor. Proses ekstraksi fitur ditunjukkan pada Gambar 5.

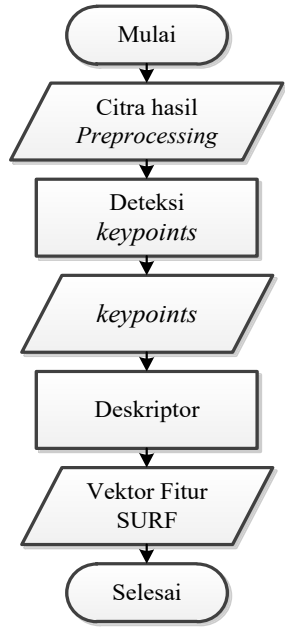

Gambar 5. Alur tahap Ekstraksi Fitur

Speed-Up Robust Features (SURF) merupakan sebuah metode deteksi fitur yang menggunakan keypoint dari sebuah citra (Oksaputri, Ernawati and Desi Andreswari, 2018). Deteksi fitur merupakan proses mengolah citra untuk mengekstrasi fitur-fitur yang unik dari suatu objek di dalam citra, tujuannya agar objek dapat dideteksi pada citra lain yang mengandung objek yang sama meskipun objek mengalami perubahan skala ataupun rotasi (Ariel, Atmaja and Azizah, 2017). Sedangkan keypoint itu sendiri adalah bagian-bagian dari sebuah citra yang nilainya tetap ketika mengalami perubahan skala, rotasi dan pencahayaan (Al-asadi and Obaid, 2016). SURF mampu mendeteksi fitur lokal suatu citra dengan handal dan cepat (Bay, Tuytelaars and Gool, 2006).

Pada algoritma SURF dipilih detektor keypoint yang mempunyai sifat invarian terhadap skala, yaitu blob detection (Bay et al., 2008). Blob merupakan area pada citra digital yang memiliki sifat bervariasi dalam kisaran tertentu. Untuk melakukan komputasi blob detection digunakan determinan matriks Hessian (DoH) dari citra. Jika diberikan titik $x=$ $(x, y)$ pada citra I, matriks Hessian $\mathrm{H}(x, \sigma)$ pada $x$ dengan skala $\sigma$ dinotasikan pada persamaan (2).

$\mathrm{H}(x, \sigma)=\left[\begin{array}{ll}L_{x x}(\mathrm{x}, \sigma) & L_{x y}(\mathrm{x}, \sigma) \\ L_{x y}(\mathrm{x}, \sigma) & L_{y y}(\mathrm{x}, \sigma)\end{array}\right]$

Tahapan selanjutnya yaitu feature description, bertujuan mendapatkan deskripsi dari fitur - fitur dalam citra yang diamati. Diawali dengan melihat orientasi yang dominan pada keypoint pada citra, kemudian membangun sesuatu area yang akan diambil nilainya menggunakan filter wavelet Haar yang dapat ditentukan tingkat kemiringan suatu fitur yang diamati. Selanjutnya untuk feature description dalam SURF digunakan hanya perhitungan gradient histogram dalam empat kelompok, yaitu $V=$ $\left(\sum d_{x}, \sum\left|d_{x}\right|, \sum d_{y}, \sum\left|d_{y}\right|\right)$, dengan $d_{x}$ respon haar wavelet pada arah horizontal dan $d_{y}$ arah vertikal. Respon wavelet juga invarian terhadap pencahayaan, 
sedangkan sifat invarian terhadap kontras dicapai melalui pembentukan deskriptor kedalam satuan vektor (Bay, Tuytelaars and Gool, 2006).
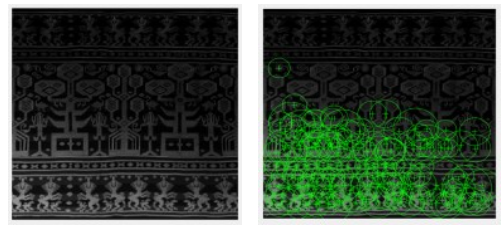

(a)

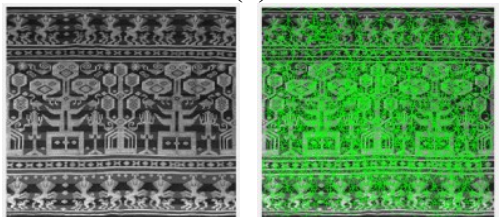

(b)

Gambar 6. Deteksi keypoint (a) Hasil deteksi keypoint tanpa CLAHE (b) Hasil deteksi keypoint dengan CLAHE

Gambar 6 menunjukkan hasil deteksi keypoint, pada bagian (a) merupakan hasil deteksi keypoint tanpa melalui proses pemerataan histogram dengan CLAHE, sehinggah dapat dilihat secara visual bahwa hasil keypoint tidak secara merata terdeteksi, ada bagian-bagian motif tenun yang tertutup oleh bayangan tidak dapat dideteksi keypoint-nya. Namun yang terjadi pada gambar 4 bagian (b) keypoint pada citra tenun dapat dideteksi secara merata pada setiap motifnya karena menggunakan CLAHE terlebih dahulu sebelum ekstraksi fitur dengan SURF untuk mendapatkan keypoint. Konsep dari Contrast Limited Adaptive Histogram Equalization (CLAHE) adalah meningkatkan kontras citra dengan meningkatkan kontras relatif tiap piksel untuk regional lokal, dimana dapat meningkatkan kekontrasan suatu citra secara lokal sehingga dapat memunculkan bagian yang tidak terlihat atau hidden feature (Joo and Jeon, 2017).

\subsection{Representasi Fitur dengan Bag of Visual Words (BoVW)}

Bag of Visual Words (BoVW) dapat digunakan dalam pengkategorian objek dengan membangun sebuah kamus besar dari banyaknya kata visual dan merepresentasikan setiap citra sebagai sebuah histogram frekuensi kata yang ada pada citra.

Fitur SURF memiliki dimensi tinggi, untuk temu kembali citra fitur SURF perlu mengurangi dimensi ruang fitur. Oleh karena itu, Bag of Visual Words digunakan sebagai pendekatan untuk mengatasi masalah ini dengan mengkuantisasi deskriptor menjadi "visual word," sehingga dapat menurunkan jumlah deskriptor secara drastis (Aditya and Supriyanto, 2015).

Adapun tahapan dari Bag of Visual Words (BoVW) yaitu, (1) Deteksi dan deskripsi fitur gambar menggunakan deskriptor fitur lokal. (2) Pengelompokan deskriptor ke set klaster (vocabulary) dengan algoritma kuantisasi vektor menggunakan K-means. (3) Pembuatan Bag of Features, yang menghitung jumlah fitur yang dimasukkan pada setiap klaster, konversi gambar menjadi satu set visual word (vocabulary) (Kato, 1992). Gambar 7 menunjukkan alur dari Bag of Visual Words (BoVW).

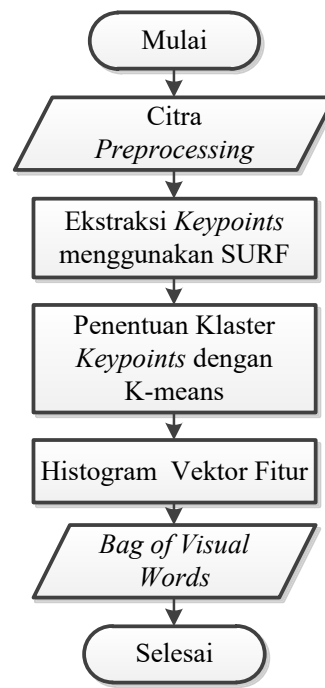

Gambar 7. Alur tahap Bag of Visual Words

\subsection{Maximally Stable Extremal Regions (MSER)}

Algoritma Maximally Stable Extremal Regions (MSER) merupakan regions detector secara dasar. Dimulai dengan melakukan pemilihan atau sortir urutan piksel-piksel dari intensitas rendah ke intensitas tinggi atau sebaliknya (misalnya pada citra grayscale mempunyai intensitas 0 sampai 255 , hal ini merupakan dasar perhitungan MSER. Intensitas tersebut yang dinamakan dengan threshold. Iterasi diawali dari threshold rendah 0 ke threshold tinggi 255 dan pada setiap threshold dilakukan perhitungan area. Dimana area yang tidak mengalami perubahan ketika threshold diubah dinamakan MSER regions. MSER banyak digunakan pada aplikasi text localization and recognition (Su et al., 2017).

Algoritma Maximally Stable Extremal Regions (MSER) terdiri dari beberapa tahapan utama yang dapat dijelaskan sebagai berikut:

- Seluruh piksel diurutkan berdasarkan intensitas.

- Satu persatu piksel diletakkan berdasar urutan intensitas di dalam citra, lalu pembaharuan struktur keterkaitan komponen dilakukan, berasal dari tingkatan area-area extremal.

- Variasi area dihitung dari setiap area-area extremal.

- Melalui tingkatan area-area extremal. Mencari satu maximally stable extremal yang memiliki "var" terkecil dari tingkat utama.

\subsection{Tenun Nusa Tenggara Timur}

Kain tenun dari setiap daerah di Nusa Tenggara Timur memiliki ciri khas motif masing-masing yang merupakan bentuk manifestasi kehidupan sehari- 
hari, kebudayaan dan kepercayaan masyarakat setempat. Ragam hias yang terdapat dalam motif tenun Nusa Tenggara Timur seperti flora, fauna dan geometris yang dihasilkan dari teknik fusuk, buna dan sotis menjadi suatu keunikan yang membedakan setiap daerah asal dan filosofi suatu motif (Tallo, 2003). Kain tenun Nusa Tenggara Timur adalah kain yang dibuat dari proses menenun. Tenun sendiri merupakan kegiatan membuat kain dengan cara memasukkan benang pakan secara horizontal pada benang-benang lungsi, biasanya telah diikat terlebih dulu dan sudah dicelupkan ke pewarna alami atau sintetis. Selain beragam motifnya, proses pembuatannya pun tak sembarangan, yaitu melalui proses ritual dengan doa sakral. Kain tenun Nusa Tenggara Timur bukan sekedar kain biasa, melainkan juga memiliki jiwa (Haning, 2013).

Kain adat atau tenun mempunyai banyak fungsi penggunaan di masyarakat, meski tiap daerah ada penggunaan khusus di tiap suku. Fungsi dari Kain Tenun Nusa Tenggara Timur yaitu sebagai busana untuk penggunaan sehari-hari dan mentupi badan. Sebagai busana dalam tari adat dan upacara adat. Sebagai mahar dalam perkawinan dalam bahasa daerah disebut sebagai belis nikah. Sebagai pemberian dalam acara kematian dan sebagai wujud penghargaan. Sebagai penunjuk status sosial. Sebagai alat untuk membayar hukuman jika terjadi ketidak seimbangan. Sebagai alat barter atau transaksi. Sebagai bentuk cerita mengenai mitos yang tergambar pada motifnya. Sebagai bentuk penghargaan bagi tamu yang datang berkunjung (La'a and Suwartiningsih, 2013). Contoh citra tenun Nusa Tenggara Timur dijelaskan pada Gambar 6.

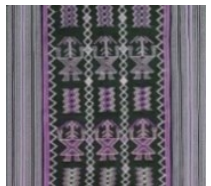

(a)

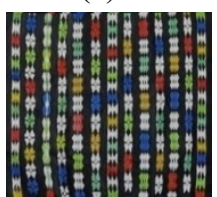

(d)

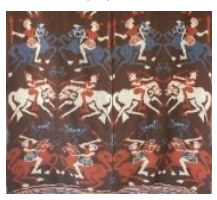

(g)

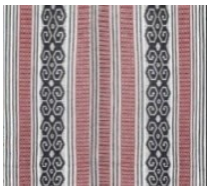

(b)

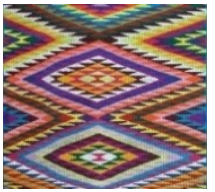

(e)

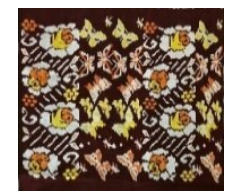

(h)

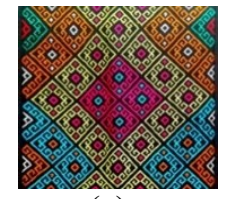

(c)

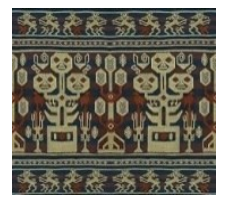

(f)

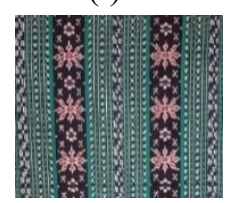

(i)
Gambar 6.Ragam motif tenun Nusa Tenggara Timur, (a) ayotupas (b) boti, (c) buna, (d) mengger, (e) naisa, (f) pahikung, (g) pasolla, (h) rose, (i) rote.

\section{HASIL DAN PEMBAHASAN}

Pengujian pada penelitian ini dibagi menjadi dua tahap yaitu skenario uji dan skenario hasil.

\subsection{Skenario Uji}

Di bagian ini, jelaskan hasil tes dari setiap skenario yang telah dilakukan. Uji coba pada penelitian ini dilakukan pada citra tenun Nusa Tenggara Timur. Citra yang digunakan adalah citra tenun Nusa Tenggara Timur yang memiliki motif flora, fauna dan geometris yang dihasilkan dari teknik fusuk, buna dan sotis. Citra tenun Nusa Tenggara Timur yang digunakan sebanyak 540 citra dengan 9 motif yang berbeda, yang terdiri dari citra query sebagai data uji sebanyak 360 dan citra dataset sebagai data latih sebanyak 180. Pada citra query, dari masing-masing motif tenun memiliki variasi rotasi dengan sudut $45^{\circ}, 90^{\circ}, 135^{\circ}$ dan $180^{\circ}$. Sedangkan untuk variasi skalanya, citra tenun diperbesar dan diperkecil dalam rentang 25\% dan $50 \%$. Selanjutnya untuk variasi cahaya, terdapat citra yang memiliki pencayaan yang tidak merata, akibat proses pengambilan citra yang kurang memperhatikan kondisi citra yang terpapar cahaya atau bayangan pada saat proses pengambilan citra. Atau akan dilakukan dengan menggunakan software editing pada citra tenun dengan memberikan efek kontras yang kurang merata. Contoh variasi kondisi citra query tenun dijelaskan pada Gambar 7 dan dataset citra tenun dijelaskan pada Tabel 1.
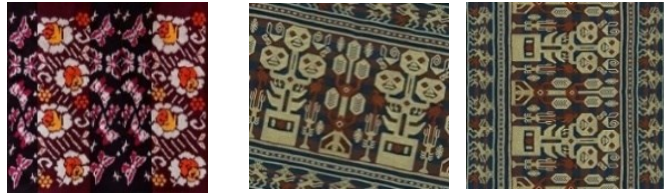

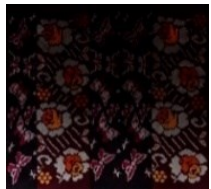

(a)
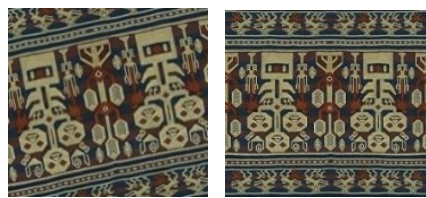

(b)
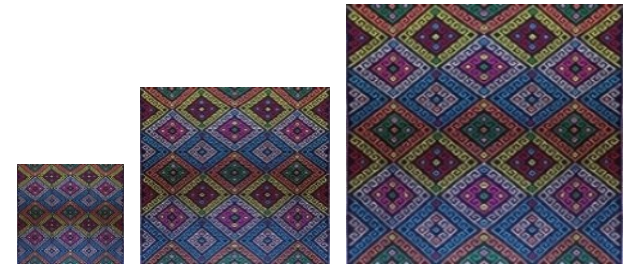

(c)

Gambar 7. Citra tenun (a) Citra tenun kondisi normal dan Citra tenun dengan gangguan pencahayaan, (b) Citra tenun dengan rotasi, (c) Citra tenun dengan skala

Tabel 1. Dataset citra tenun

\begin{tabular}{|c|c|c|c|c|}
\hline \multirow{2}{*}{ Motif } & \multirow{2}{*}{$\begin{array}{l}\text { Jumlah } \\
\text { Dataset }\end{array}$} & \multicolumn{3}{|c|}{ Jumlah citra query } \\
\hline & & Rotasi & Skala & Cahaya \\
\hline Ayotupas & 20 & 16 & 16 & 8 \\
\hline Boti & 20 & 16 & 16 & 8 \\
\hline Buna & 20 & 16 & 16 & 8 \\
\hline Mengger & 20 & 16 & 16 & 8 \\
\hline Naisa & 20 & 16 & 16 & 8 \\
\hline Pahikung & 20 & 16 & 16 & 8 \\
\hline Pasolla & 20 & 16 & 16 & 8 \\
\hline Rose & 20 & 16 & 16 & 8 \\
\hline Rote & 20 & 16 & 16 & 8 \\
\hline Total & 180 & & 360 & \\
\hline
\end{tabular}


Dalam penelitian ini, ada 2 skenario yang diimplementasikan dalam menguji metode temu kembali citra tenun yang diusulkan. Skenario pertama adalah menguji efek pemilihan jumlah vocabulary yang digunakan dan selanjutnya adalah efek penentuan jumlah keypoint pada citra tenun. Jumlah vocabulary untuk membangun model clustering adalah faktor substansial yang berdampak pada akurasi temu kembali citra tenun. Tujuan utama bagian ini adalah untuk menganalisis berapa banyak cluster yang cukup stabil untuk meningkatkan akurasi menggunakan SURF pada citra tenun. Jumlah cluster yang diimplementasikan adalah 4000, 5000 dan 6000. Sedangkan penentuan jumlah keypoint pada citra juga dilakukan untuk menganalisis berapa banyak keypoint yang cukup stabil untuk meningkatkan akurasi dan mengurangi waktu komputasi dalam membangun Bag of Visual Words (BoVW).

\subsection{Hasil dan Analisis}

Hasil pengujian dari percobaan temu kembali citra tenun ditunjukkan pada Tabel 4 dan Tabel 5 yang menjelaskan hasil dari percobaan pada citra query dengan kondisi normal dan citra query dengan gangguan pencahayaan. Sedangkan pada Tabel 6, Tabel 7, dan Tabel 8 menunjukkan hasil percobaan pada citra query yang diberi rotasi. Adapun hasil percobaan pada citra query yang diberi skala di tunjukkan pada Tabel 9, Tabel 10, dan Tabel 11. Dan yang terakhir adalah hasil percobaan pada seluruh kondisi citra tenun dan waktu komputasinya yang ditunjukkan pada Tabel 12 dan Tabel 13. Pada setiap kondisi data citra tenun diimplementasikan dalam dua skenario percobaan, yaitu pemilihan jumlah vocabulary dan selanjutnya adalah penentuan jumlah keypoint pada citra tenun yang akan digunakan.

Pada penelitian ini Metode evaluasi yang digunakan untuk mengukur keandalan metode pada sistem temu kembali citra tenun Nusa Tenggara Timur menggunakan akurasi. Proses perhitungan accuracy, ditentukan dari prediksi informasi pada nilai aktual yang diwakili oleh True Positive (TP), True Negative (TN), False Positive (FP), dan False Negative (FN). Akurasi adalah ukuran dari hasil eksperimen yang menghitung rasio kebenaran dari semua data. Persamaan dari metode evaluasi accuracy ditunjukkan dalam persamaan 3 .

Accuracy $=\frac{T P+T N}{T P+F P+F N+T N}$

Contoh hasil temu kembali citra tenun menggunakan citra query tenun motif buna dengan kondisi normal mendapatkan akurasi $100 \%$ dan hasil temu kembali menggunakan citra query dengan skala diperkecil $50 \%$ mendapatkan hasil akurasi 60\%. Contoh dapat dilihat pada Tabel 2 dan Tabel 3.

Tabel 2. Hasil temu kembali citra tenun dengan kondisi citra query normal

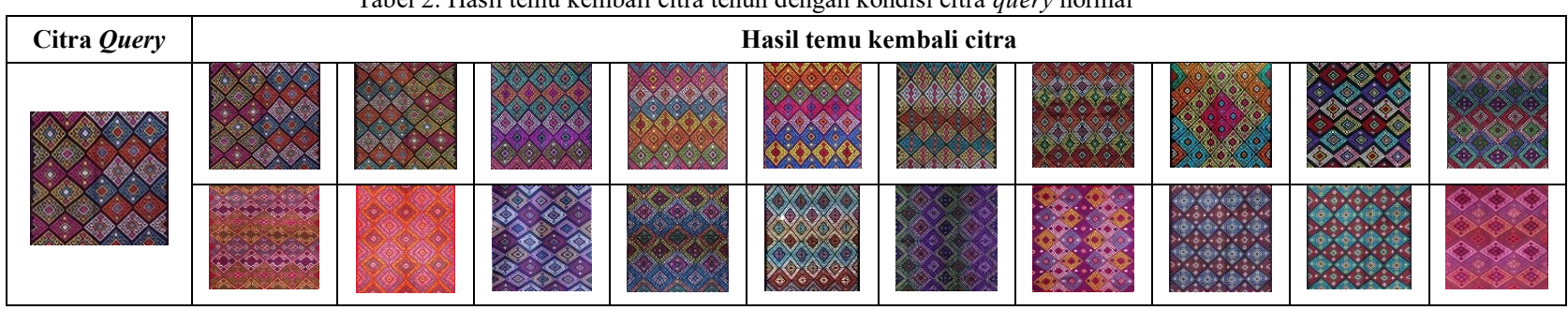

Tabel 3. Hasil temu kembali citra tenun dengan kondisi citra query skala diperkecil 50\%

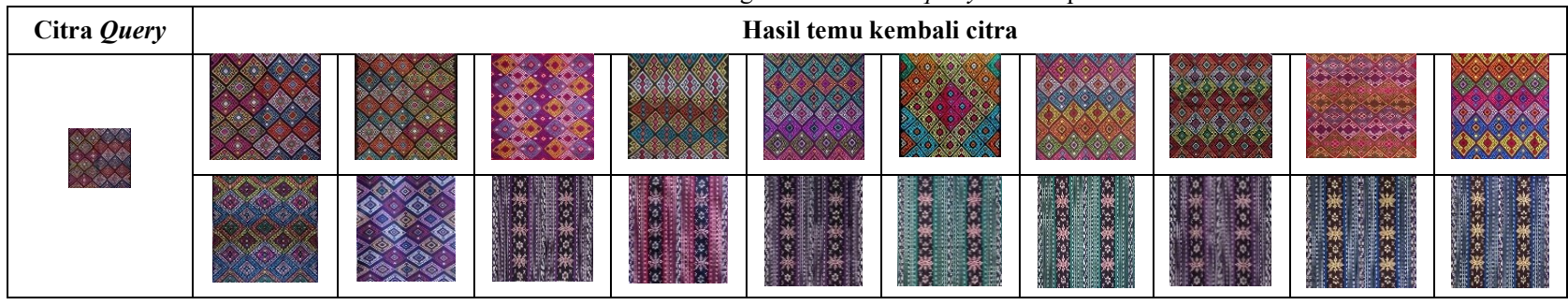

Tabel 4. Hasil pengujian pada kondisi citra tenun dengan kondisi normal

\begin{tabular}{llll}
\hline Jumlah Cluster & \multicolumn{3}{c}{ Jumlah Keypoint } \\
& $\mathbf{1 0 0 0 0}$ & $\mathbf{1 5 0 0 0}$ & Seluruh \\
\hline $\mathbf{4 0 0 0}$ & 92,22 & 91,66 & 91,80 \\
$\mathbf{5 0 0 0}$ & $\mathbf{9 3 , 0 5}$ & 92,36 & 92,22 \\
$\mathbf{6 0 0 0}$ & 92,63 & 92,08 & 91,66 \\
\hline
\end{tabular}

Tabel 5. Hasil pengujian pada kondisi citra tenun dengan gangguan pencahayaan Jumlah Cluster Jumlah Keypoint

\begin{tabular}{llll} 
& $\mathbf{1 0 0 0 0}$ & $\mathbf{1 5 0 0 0}$ & Seluruh \\
\hline $\mathbf{4 0 0 0}$ & 90,55 & 89,72 & 90,00 \\
$\mathbf{5 0 0 0}$ & $\mathbf{9 1 , 5 2}$ & 89,30 & 90,41 \\
$\mathbf{6 0 0 0}$ & 90,55 & 89,02 & 89,16 \\
\hline
\end{tabular}


356 Jurnal Teknologi Informasi dan Ilmu Komputer (JTIIK), Vol. 7, No. 2, April 2020, hlm. 349-358

\begin{tabular}{lcccc}
\multicolumn{4}{c}{ Tabel 6. Hasil pengujian dengan seluruh keypoint pada kondisi citra tenun yang dirotasi } \\
\hline Jumlah Cluster & \multicolumn{4}{c}{ Citra Rotasi } \\
& $\mathbf{4 5}^{\mathbf{0}}$ & $\mathbf{9 0}^{\mathbf{0}}$ & $\mathbf{1 3 5}^{\mathbf{0}}$ & $\mathbf{1 8 0}^{\mathbf{0}}$ \\
\hline $\mathbf{4 0 0 0}$ & 89,72 & 91,80 & 90,97 & 91,25 \\
$\mathbf{5 0 0 0}$ & 90,27 & 92,50 & 90,55 & $\mathbf{9 2 , 0 8}$ \\
$\mathbf{6 0 0 0}$ & 89,86 & 91,66 & 90,41 & 91,52 \\
\hline
\end{tabular}

Tabel 7. Hasil pengujian dengan 15000 keypoint pada kondisi citra tenun yang dirotasi

\begin{tabular}{lcccc}
\hline Jumlah Cluster & \multicolumn{4}{c}{ Citra Rotasi } \\
& $\mathbf{4 5}^{\mathbf{0}}$ & $\mathbf{9 0}^{\mathbf{0}}$ & $\mathbf{1 3 5}^{\mathbf{0}}$ & $\mathbf{1 8 0}^{\mathbf{0}}$ \\
\hline $\mathbf{4 0 0 0}$ & 86,80 & 91,52 & 86,94 & 91,11 \\
$\mathbf{5 0 0 0}$ & 87,50 & 92,36 & 88,05 & $\mathbf{9 1 , 5 2}$ \\
$\mathbf{6 0 0 0}$ & 86,38 & 91,66 & 87,08 & 91,25 \\
\hline
\end{tabular}

Tabel 8. Hasil pengujian dengan 10000 keypoint pada kondisi citra tenun yang dirotasi

\begin{tabular}{lcccc}
\hline Jumlah Cluster & \multicolumn{4}{c}{ Citra Rotasi } \\
& $\mathbf{4 5}^{\mathbf{0}}$ & $\mathbf{9 0}^{\mathbf{0}}$ & $\mathbf{1 3 5}^{\mathbf{0}}$ & $\mathbf{1 8 0}^{\mathbf{0}}$ \\
\hline $\mathbf{4 0 0 0}$ & 89,16 & 92,36 & 89,16 & 91,80 \\
$\mathbf{5 0 0 0}$ & 89,72 & $\mathbf{9 3 , 0 5}$ & 90,13 & 92,50 \\
$\mathbf{6 0 0 0}$ & 88,88 & 92,36 & 89,02 & 92,22 \\
\hline
\end{tabular}

Tabel 9. Hasil pengujian dengan seluruh keypoint pada kondisi citra tenun berskala

\begin{tabular}{|c|c|c|c|c|}
\hline \multirow{3}{*}{ Jumlah Cluster } & \multicolumn{4}{|c|}{ Citra Skala } \\
\hline & \multicolumn{2}{|c|}{ Perkecil } & \multicolumn{2}{|c|}{ Perbesar } \\
\hline & $25 \%$ & $50 \%$ & $25 \%$ & $50 \%$ \\
\hline 4000 & 91,80 & 79,86 & 90,69 & 89,44 \\
\hline 5000 & 90,97 & 80,00 & 90,41 & 89,16 \\
\hline 6000 & 91,25 & 80,13 & 90,13 & 89,16 \\
\hline \multicolumn{5}{|c|}{ Tabel 10. Hasil pengujian dengan 15000 keypoint pada kondisi citra tenun berskal } \\
\hline \multirow[t]{3}{*}{ Jumlah Cluster } & \multicolumn{4}{|c|}{ Citra Skala } \\
\hline & \multicolumn{2}{|c|}{ Perkecil } & \multicolumn{2}{|c|}{ Perbesar } \\
\hline & $25 \%$ & $50 \%$ & $25 \%$ & $50 \%$ \\
\hline 4000 & 90,27 & 76,25 & 82,91 & 61,11 \\
\hline 5000 & 89,16 & 75,55 & 83,88 & 61,52 \\
\hline 6000 & 89,72 & 75,13 & 83,05 & 61,66 \\
\hline
\end{tabular}

Tabel 11. Hasil pengujian dengan 10000 keypoint pada kondisi citra tenun berskala

\begin{tabular}{lcccc}
\hline Jumlah Cluster & \multicolumn{3}{c}{ Perkecil } & $\mathbf{2}$ Perbesar \\
\cline { 2 - 5 } & $\mathbf{2 5 \%}$ & $\mathbf{5 0 \%}$ & $\mathbf{2 5 \%}$ & $\mathbf{5 0 \%}$ \\
\hline $\mathbf{4 0 0 0}$ & 85,00 & 68,33 & 85,13 & 62,36 \\
$\mathbf{5 0 0 0}$ & 85,83 & 70,41 & $\mathbf{8 6 , 5 2}$ & 63,47 \\
$\mathbf{6 0 0 0}$ & 85,00 & 68,88 & 85,55 & 63,75 \\
\hline
\end{tabular}

Tabel 12. Hasil pengujian pada seluruh kondisi citra tenun

\begin{tabular}{lccc}
\hline Jumlah Cluster & \multicolumn{3}{c}{ Jumlah Keypoint } \\
& $\mathbf{1 0 0 0 0}$ & $\mathbf{1 5 0 0 0}$ & Seluruh \\
\hline $\mathbf{4 0 0 0}$ & 84,61 & 84,83 & 89,73 \\
$\mathbf{5 0 0 0}$ & 85,62 & 85,12 & $\mathbf{8 9 , 8 6}$ \\
$\mathbf{6 0 0 0}$ & 84,88 & 84,70 & 89,50 \\
\hline \multicolumn{4}{c}{} \\
& Tabel 13. Waktu komputasi \\
\hline Jumlah Cluster & \multicolumn{3}{c}{ Jumlah Keypoint } \\
& $\mathbf{1 0 0 0 0}$ & $\mathbf{1 5 0 0 0}$ & Seluruh \\
\hline $\mathbf{4 0 0 0}$ & 6.81 & 8.09 & 9.00 \\
$\mathbf{5 0 0 0}$ & 6.83 & 7.92 & 9.94 \\
$\mathbf{6 0 0 0}$ & 7.43 & 8.62 & 10.28 \\
\hline
\end{tabular}

Hasil percobaan ditunjukkan pada Tabel 4 hingga Tabel 13 yang menjelaskan hasil percobaan dengan menggunakan ekstraksi fitur SURF. Setiap skenario diimplementasikan dalam empat kondisi data citra query dengan pemilihan jumlah vocabulary dan penentuan jumlah keypoint yang digunakan. Sedangkan Tabel 14 dan Tabel 15 menjelaskan hasil perbandingan antara metode ekstraksi fitur SURF yang berbasis keypoint dengan Maximally Stable Extremal Regions (MSER) yang berbasis regions detector.
Dalam percobaan menggunakan data citra query dengan kondisi normal tanpa rotasi, skala dan gangguan pencahayaan, dilakukan menggunakan seluruh keypoint, 15000 keypoint dan 10000 keypoint. Untuk jumlah cluster mendapatkan 5000 sebagai jumlah cluster yang terbaik. Hasilnya menunjukkan bahwa akurasi tertinggi adalah 93,05\% yang menggunakan 10000 keypoint dengan 5000 cluster. Dari skenario ini dibuat untuk mengetahui berapa jumlah klaster terbaik yang dapat memberikan hasil yang lebih baik. Seperti yang 
telah dijelaskan, vocabulary harus pas (tidak terlalu besar sehingga dapat membedakan perubahan yang relevan dalam bagian citra dan tidak terlalu kecil sehingga dapat membedakan variasi yang tidak relevan seperti noise). Sedangkan hasil terendah adalah 91,66\% dengan menggunakan 4000 cluster. Hasil percobaan ditunjukkan pada Tabel 4.

Skenario berikutnya adalah melakukan pengujian pada citra yang memiliki gangguan pencayaan atau motif tenun yang tertutup oleh bayangan. Hasil akurasi penelitian tertinggi diberikan pada citra dengan gangguan pencahayaan adalah 91,52\% dengan menggunakan seluruh keypoint dan menggunakan 5000 cluster. Sedangkan hasil terendah adalah $89,02 \%$ dengan menggunakan 15000 keypoint dan menggunakan 6000 cluster. Pada kondisi citra query ini cukup stabil karena nilai akurasinya mendekati citra dengan kondisi normal, karena telah dilakukan preprocessing terlebih dahulu. Hasil percobaan ditunjukkan pada Tabel 5.

Skenario selanjutnya adalah melakukan pengujian pada citra query yang rotasi dengan sudut $45^{\circ}, 90^{\circ}, 135^{\circ}$ dan $180^{\circ}$. Hasil menunjukkan bahwa akurasi tertinggi adalah $93,05 \%$ pada citra query rotasi dengan sudut $90^{\circ}$ yang menggunakan 10000 keypoint dengan 5000 cluster. Sedangkan hasil terendah adalah $86,38 \%$ pada citra query rotasi $45^{\circ}$ dengan menggunakan 15000 keypoint dan 6000 cluster. Citra query yang dirotasi dengan $45^{\circ}$ dan $135^{\circ}$ hampir di semua motif mendapatkan akurasi yang rendah disebabkan karena adanya beberapa citra tenun yang memiliki kemiripan motif namun motif dominan yang mirip pada tenun tidak termasuk ciri khasnya. Sehinggah apabila dirotasi dengan sudut $45^{\circ}$ dan $135^{\circ}$ akan mengurangi dan merubah sebagian ciri khas motif yang kurang dominan pada tenun yang mengakibatkan menurunnya akurasi yang didapat. Hasil percobaan ditunjukkan pada Tabel 6, Tabel 7 dan Tabel 8.
Skenario terakhir adalah melakukan pengujian pada citra query dengan skala yang diperbesar dan diperkecil menjadi $25 \%$ dan $50 \%$. Hasil penelitian menunjukkan akurasi tertinggi diperoleh pada saat citra query diperkecil dengan skala $25 \%$ mendapatkan akurasi 91,80\% dengan menggunakan seluruh keypoint dan 4000 cluster. Sedangkan hasil terendah adalah $61,11 \%$ untuk citra query yang diperbesar hingga 50\% dengan menggunakan 15000 keypoint dan menggunakan 4000 cluster. Pada citra query yang diperbesar 50\% mendapatkan akurasi yang rendah karena terjadinya peningkatan jumlah keypoint, sehinggah terjadinya penurunan akurasi. Hasil percobaan ditunjukkan pada Tabel 9, Tabel 10 dan Tabel 11.

Sedangkan hasil rata-rata akurasi pada keseluruhan kondisi citra tenun, yang mendapatkan akurasi rata-rata tertinggi adalah $89,86 \%$ dengan menggunakan seluruh keypoint dan menggunakan 5000 cluster. Sedangkan hasil rata-rata terendah pada keseluruhan kondisi citra tenun adalah 84,61\% dengan menggunakan 10000 keypoint dan menggunakan 4000 cluster. Untuk waktu komputasi dalam membangun Bag of Visual Words (BoVW), waktu tercepat ditunjukkan pada penggunaan jumlah keypoint 10000 dengan jumlah cluster 4000. Semakin banyak jumlah keypoint akan memakan waktu komputasi yang lebih lama namun memiliki akurasi yang lebih baik. Dengan menggunakan seluruh keypoint dan 5000 cluster mendapatkan hasil akurasi terbaik yaitu $89,86 \%$, namun ketika dinaikan jumlah cluster menjadi 6000 akurasi menurun menjadi $89,5 \%$, ini menunjukkan bahwa semakin banyak jumlah cluster belum tentu dapat menghasilkan akurasi yang meningkat. Hasil percobaan ditunjukkan pada Tabel 12 dan Tabel 13.

Tabel 14. Hasil perbandingan pengujian pada temu kembali citra tenun

\begin{tabular}{|c|c|c|c|c|c|c|c|c|c|c|}
\hline \multirow{3}{*}{ Metode } & \multirow{2}{*}{\multicolumn{2}{|c|}{ Citra }} & \multirow{2}{*}{\multicolumn{4}{|c|}{ Citra Rotasi }} & \multicolumn{4}{|c|}{ Citra Skala } \\
\hline & & & & & & & \multicolumn{2}{|c|}{ Perkecil } & \multicolumn{2}{|c|}{ Perbesar } \\
\hline & Normal & Pencahayaan & $45 \%$ & $90 \%$ & $135 \%$ & $180 \%$ & $25 \%$ & $50 \%$ & $25 \%$ & $50 \%$ \\
\hline SURF & 92,22 & 90,41 & 90,27 & 92,5 & 90,55 & 92,08 & 90,97 & 80 & 90,41 & 89,16 \\
\hline MSER & 88,33 & 87,08 & 84,30 & 87,36 & 86,80 & 87,77 & 82,77 & 73,05 & 86,66 & 80,55 \\
\hline
\end{tabular}

Tabel 15. Hasil perbandingan rata-rata akurasi pengujian dan waktu komputasi

\begin{tabular}{lrr} 
Metode & Akurasi Rata-rata & \multicolumn{2}{c}{ Waktu Komputasi } \\
\hline SURF & $\mathbf{8 9 , 8 6}$ & 9,94 \\
MSER & 84,04 & $\mathbf{1 , 9 5}$ \\
\hline
\end{tabular}

Algoritma Maximally Stable Extremal Regions (MSER) secara dasar adalah regions detector. MSER adalah detector yang mencari wilayah yang lebih terang atau gelap dari pada sekitarnya. Pada penelitian ini, dilakukan perbandingkan metode ekstrasi fitur pada temu kembali citra tenun Nusa Tenggara Timur dengan membandingkan antara metode ekstraksi fitur Speeded Up Robust Feature (SURF) yang berbasis keypoint dengan Maximally Stable Extremal Regions (MSER) yang berbasis regions detector. Dari hasil percobaan yang ditunjukkan pada Tabel 14 dan 15 menjelaskan bahwa hasil dari SURF memiliki akurasi yang lebih tinggi pada semua kondisi data citra tenun dengan nilai rata-rata akurasi $89,86 \%$, sedangkan MSER mendapatkan akurasi $84,04 \%$. Namun jika dilihat dari segi waktu komputasi pada Tabel 15 MSER memiliki waktu lebih cepat yaitu 1,95 detik dibandingkan SURF yaitu 9,94 detik. 


\section{KESIMPULAN}

Pada penelitian ini telah dibangun sistem temu kembali citra tenun menggunakan beberapa tahapan proses yaitu mengubah gambar RGB menjadi gambar grayscale serta melakukan perbaikan citra dengan CLAHE, ekstraksi fitur menggunakan Speeded Up Robust Feature (SURF) dengan representasi fitur menggunakan model Bag of Visual Words (BoVW). Sistem yang dibangun telah mampu mengidentifikasi jenis citra tenun dengan sangat baik. Berdasarkan hasil analisis yang diperoleh, akurasi temu kembali citra ditentukan oleh jumlah cluster atau jumlah vocabulary yang tepat. Sedangkan jumlah keypoint yang digunakan berpengaruh terhadap waktu komputasi.

Untuk keseluruhan proses temu kembali citra dengan menggunakan perbaikan citra CLAHE, ekstraksi SURF dan representasi fitur BoVW menunjukkan bahwa sistem ini dengan tepat dapat mengenali citra tenun yang memiliki variasi rotasi, skala dan pencahayaan pada temu kembali citra tenun. Dengan penggunaan seluruh keypoint dengan 5000 cluster sistem mendapatkan akurasi rata-rata pada semua kondisi data citra query sebesar $89,86 \%$ dengan waktu komputasi 9.94 detik. Sedangkan hasil akurasi yang didapatkan dengan mengunakan ekstraksi fitur berbasis regions detector yaitu MSER dengan perbaikan citra CLAHE mendapat akurasi lebih rendah sebesar 84,04\% namun memiliki waktu komputasi lebih cepat yaitu 1.95 detik.

\section{DAFTAR PUSTAKA}

ADIKARA, P. P. (2018) 'Pencarian Produk Yang Mirip Melalui Automatic Online Annotation Dari Web Dan Berbasiskan Konten Dengan Color Histogram Bin dan Surf Descriptor'.

ADITYA, A. E. \& SUPRIYANTO, C. (2015) 'Descriptor Clustering SURF for Bag of Visual Words Representation in Fingerprint Images Using K-MEANS and Hierarchical Agglomerative Clustering'.

AL-ASADI, T. A. \& OBAID, A. J. (2016) 'Object detection and recognition by using enhanced Speeded Up Robust Feature', International Journal of Computer Science and Network Security, pp. 66-71.

ALKHAWLANI, M., ELMOGY, M. \& ELBAKRY, H. (2015) 'Content-Based Image Retrieval using Local Features Descriptors and Bag-of-Visual Words', International Journal of Advanced Computer Science and Applications. doi: 10.14569/IJACSA.2015.060929.

AMALIA, I., INDRAWATI \& YUSNIMAR M. AMIN (2018) 'Ekstraksi Fitur Citra Songket Berdasarkan Tekstur Menggunakan Metode Gray Level Co-occurrence Matrix (GLCM)'.

ARIEL, M. B., ATMAJA, R. D. \& AZIZAH, A. (2017) 'Implementasi Metode Speed Up Robust Feature dan Scale Invariant Feature Transform untuk Identifikasi Telapak Kaki Individu', Jurnal Al-Azhar Indonesia Seri Sains dan Teknologi, pp. 178-186. Available at: http://jurnal.uai.ac.id/index.php/SST/article/view $/ 232$.

BAY, H. et al. (2008) 'Speeded-Up Robust Features (SURF)', Computer Vision and Image Understanding, pp. 346-359. doi: 10.1016/j.cviu.2007.09.014.

BAY, H., TUYTELAARS, T. \& GOOL, L. VAN (2006) 'SURF: Speeded Up Robust Features', pp. 562-589. doi: 10.1007/11744023_32.

HANING, B. (2013) 'Raga Ragam Tenun NTT'.

ISMAIL, A. I., ALI, H. S. \& FARAG, F. A. (2015) 'Efficient Enhancement and Matching for Iris Recognition using SURF'.

JOO, H.-B. \& JEON, J. W. (2017) 'Feature-Point Extraction Based on an Improved SIFT Algorithm'.

KATO, T. (1992) 'Database architecture for contentbased image retrieval', pp. 112-123. doi: 10.1117/12.58497.

LA'A，A. S. \& SUWARTININGSIH， S. (2013) 'Makna Tenun Ikat Bagi Perempuan (Studi Etnografi di Kecamatan Mollo Utara- Timor Tengah Selatan)', pp. 172-180. doi: 10.1007/BF01362716.

NASIR, M., SUCIATI, N. \& WIJAYA, A. Y. (2017) 'Kombinasi Fitur Tekstur Local Binary Pattern yang Invariant Terhadap Rotasi dengan Fitur Warna Berbasis Ruang Warna HSV untuk Temu Kembali Citra Batik', pp. 42-51.

OKSAPUTRI, R., ERNAWATI \& DESI ANDRESWARI (2018) 'Implementasi Content Based Image Retrieval (CBIR) Pada Citra Batik Besurek Yang Tidak Utuh Menggunakan Metode Speeded Up Robust Features (SURF) Dan Fast Library Approximated Nearest Neighbor (FLANN)'.

PIZER, S. M. et al. (2007) 'Contrast Limited Adaptive Histogram Equalization: Speed and Effectiveness', Livestock Research for Rural Development.

SETIAWAN, B. (2014) 'Strategy For Development Of Kupang Ikat Woven East Nusa Tenggara Province'.

SETIOHARDJO, N. M. \& HARJOKO, A. (2014) 'Analisis Tekstur untuk Klasifikasi Motif Kain (Studi Kasus Kain Tenun Nusa Tenggara Timur)', IJCCS (Indonesian Journal of Computing and Cybernetics Systems), pp. 177188. doi: $10.22146 /$ ijccs.6545.

SU, F. et al. (2017) 'Text Proposals Based on Windowed Maximally Stable Extremal Region for Scene Text Detection'.

TALlO, N. E. C. (2003) 'Pesona Tenun FLOBAMORA'. 